\title{
COVID-19 pandemic preventive guidelines and protocols: How does this affect the Yoruba funeral rites in Nigeria
}

\author{
Joseph Oluyemi Adesoji ${ }^{1^{*}}$, Fagbamila Olumide David ${ }^{2}$, Joseph Adejoke Adijat ${ }^{3}$ \\ ${ }^{1}$ Department of Sociology and Anthropology, Nelson Mandela University, Port Elizabeth, South Africa \\ ${ }^{2}$ Department of Sociology, University of Ilorin, Nigeria. \\ ${ }^{3}$ Department of Microbial Pathology University of Medical Sciences, Ondo, Nigeria \\ ${ }^{*}$ Corresponding author. Email: josepholuyemi1@gmail.com
}

(Received 22 July 2021; Accepted 05 November 2021; Published 30 November 2021)

\begin{abstract}
Funeral rites are significant instrument used in expressing, reaffirming and reinforcing life after death among the Yoruba' and its not just limited to burying the dead but involves a series of rituals that are performed prior to and after the burial depending on the circumstances that surrounds the death of the deceased, the religious affiliation and the community which the deceased belonged. This is usually marked by some form of celebration especially when the deceased is said to have lived a fulfilled life and died at a ripe old age. However, with the unprecedented COVID-19 pandemic and subsequent preventive guidelines and protocols outlined by the World Health Organization that are expected to be implemented by various governments all over the world including Nigeria, there are indications that the funeral rites may have been altered. This study therefore examined the effects of the COVID-19 pandemic preventive guidelines and protocols on the Yoruba funeral rites. In order to substantiate some of the claims presented in the study, primary data was obtained through in-depth interview from twenty (20) participants while participants were recruited through snow ball sampling method. Data retrieved was analyzed using the qualitative data analysis program ATLAS.ti version 8. Findings from the study revealed that the COVID-19 pandemic preventive guidelines and protocols affects the Yoruba funeral rites in the areas of grieving and mourning, preparation for burial, funeral service and burial as well as burial ceremony.
\end{abstract}

Keywords: COVID-19 pandemic, Lockdown, Guidelines and protocols, Funeral rites, Death, Yoruba. 


\section{Introduction}

The Yoruba people are a major ethnic group found predominantly in the western part of Nigeria. They constitute about $21 \%$ of the population of the country, World Fact Book (2020) and are a very religious people (Hunwick 1992). Yoruba' are very expressive and exhibit rich, exuberant and ceremonial nature of their culture with colourful festivals and celebrations. Death among the Yoruba people is not only conceived as inevitable but a transition unto another phase of life.

The belief in reincarnation within the family is highly upheld as it is believed that the dead will come back to life as a new-born child in the same family (Klaudia 2021). When a person dies at a ripe old age, such death is conceived as good and as such, full funerary rites are accorded to the person (Awolalu \& Dopamu 2005). However, the unprecedented COVID-19 pandemic may have greatly altered the Yoruba funeral rites, which was usually characterised by flamboyant celebrations and diverse range of rituals and rites.

COVID-19 is primarily spread through nose and mouth secretions containing small droplets produced when coughing, sneezing and talking (World Health Organization 2020). Its symptoms are cough, fatigue, fever, breathing difficulties or shortness of breath, and loss of sense of smell (Centers for Disease Control and Prevention 2020). Currently, the disease has no cure but can be prevented by covering one's mouth when coughing, hand washing, wearing a face mask in public places, keeping distance from other people, disinfecting surfaces, increasing exposure to air and air purification indoors (Centers for Disease Control and Prevention 2020).

In order to contain the further spread of the disease and the implication arising from it, authorities all over the world-imposed travel ban, lockdowns, postponement or outright cancellation of religious, political, cultural and sporting events including burial ceremonies (Garcia et al. 2020). In Nigeria, COVID-19 has rapidly affected the daily life and activities of many with extensive and far-reaching consequences. The spread of the virus across the country caused the shut-down or lock-down of several states in the country and Federal public servants were ordered to stay at home.

Markets were shut down in many parts of the country while inter-state travels were prohibited. Social gatherings such as weddings and funerals are also strictly 
regulated by the government thereby curbing and restricting the existing flamboyant culture of celebration that the Yoruba' are accustomed to. Basic guidelines were also outlined to be adopted when burying the dead which greatly affected the way and manner that the dead is buried among the Yoruba'. These include guidelines and protocols in grieving, making funeral arrangements, holding funeral services and visitation, traditional rituals or practices, touching the corpse before preparation, selfprotection, precaution and safety were properly laid down. This study therefore examined the effects of COVID-19 pandemic preventive guidelines and protocols on the Yoruba funeral rites.

\section{The social construction of death (Iku) among the Yoruba's}

There are several ways of handling the loss of loved ones all over the world. In some cultures, it is suitable to mourn for lengthy periods of time without the disruption of work or other forms of obligations while other doesn't. But the Yoruba' have a different perception to grief or loss. Among the Yoruba' it is believed that the dead has merely transited unto another phase of life and are still with their loved ones every day.

According to the Yoruba' death is perceived as inevitable, hence the popular adage that says, awaye iku kosi, orun nikan lare mabo that is no one has ever come to this world without dying, it is only heaven that you go and not return (Aborisade 2015). Even though there is no scientific evidence of decisive survival after the death of the body, it is a generally held believe among the Yoruba' that the soul of the dead continues to exist after death.

According to Dopamu (2006), this unique belief gives a three dimension of the soul. First, it is believed that the soul is an unseen being representing an unborn invisible child in heaven. It is believed that it is this being that appears before Olodumare, the Supreme God to be given the destiny ayanmo that a person will come into the world to fulfil. Secondly, it is also believed that the soul, while invisible, animates the body of a visible person on earth and pervades it with life. Thirdly, at death the soul, in its invisible form, leaves the body of the dead person and represents the dead before Olodumare, the Supreme Being for judgement.

According to Idowu (1967) the first integral part of a person is the ara (body) which is shared with other creatures. It is the ara that performs the role of the house for other integral parts. It is the concrete, tangible thing of flesh and bones which we recognise through the senses, which can be termed in a general way, or methodically as 
anatomy (Idowu 1967). Through the ara, an individual acts and reacts the physical environment and when a person dies, it is the ara that is buried and allowed to decay. The second is okan (heart), which among the Yoruba' is a real representation of another okan which is essentially immaterial and invisible. The third is emi which is widely translated as life, spirit or being and the seat of life. The fourth element is eemi (breath). This is closely associated with emi (life). At death, when man ceases to breathe, it means that his emi has gone. The fifth element is the soul which is a pervasive concept among the Yoruba'. The Yoruba believe that the soul guides and helps a person before he is born, at birth, through the passages of life, at death, and finally goes back to its Creator, the Supreme Being, Olodumare (Awolalu \& Dopamu 2005).

Hence, the Yoruba' believe that human beings exist beyond the limits of the present mortal lifetime. This is attested to by their cultural practices of worship of the ancestors, concept of the living-dead, ancestral festivals, belief in spiritual overseers of clan activities and justice of moral offenders, the last words of the dead, transition of the dead, divine judgement and reincarnation.

Amongst the Yoruba' death is categorised into bad or good death, death of the young and of the aged. The good death occurs when an individual live to a ripe old age, and full funerary rites are accorded such a person. Bad deaths occur when a person's death is caused by anti-wickedness divinities such as thunder, iron, and smallpox, those who die young and those who die without leaving any child behind (Awolalu \& Dopamu 2005). The elderly believes that there should not be any apprehension over death since it is a means of returning home which is the origin of every human being.

Death at an old age is regarded as a blessing and is celebrated with feasting but when a young person dies it is a considered bad death among the Yoruba' hence they are not given full funeral rites to prepare him/her for the new journey home (Aborisade 2015). It is believed that death closes the door of physical bodily existence and opens the door to a new life. The elderly consequently does not confront death as a coward. The Yoruba believe that the soul of the departed must exist somewhere in heaven hence regard death as both the necessary and sufficient condition for attaining immortality of the soul.

In their popular adage, the Yoruba' does say: Aiye loja, orun nile (this means that, life is a temporal market place, heaven is the eternal home). Therefore, the Yoruba' do not perceive death as evil as long as that the dead person is aged and has lived a good life that could allow him or her to be acceptable into orun (heaven). The fact that the 
soul will live outside the body in orun (heaven) is a point that traditional Yoruba would be certain of and protect because they have an unreserved belief that God created the soul to live in the domicile of the spirit (Aborisade 2015). Funeral rites therefore are of main importance as an instrument for expressing, reaffirming and reinforcing life after death (Robertson 1969).

\section{The Yoruba funeral (Isinku) rites}

Funeral rites (isinku) among the Yoruba' is not just limited to burying the corpse but involves a chain of rituals that is performed prior and after burial of the deceased, the circumstances surrounding the death and the religious affiliation of the deceased and the community to which the deceased belonged (Aborisade 2015). In some communities, the first step taken after the death of a person is to ascertain the cause of death. If the person died of natural cause for instance, it is expected that a ritual be performed to avert the departed from further molestation of the evil spirits as well as dangers that may befall family members from such fate (Ellis 1999).

Next is iweku (washing of the corpse) where the decease body is cleansed with rum, or a decoction of fragrant herbs to make it untainted and fit for entry into the abode of the ancestors while it is dressed in its best attires. The thumbs and the great toes are then tied together and if the dead person is a male, the head is shaved, and the hair is cautiously enclosed in a piece of white cotton and, is buried in the ground behind the house. But, if the deceased is female, the hair is plaited to make her look gorgeous while the nails are neatly trimmed and the uncovered parts of the body are tarnished with a decoction which gives a reddish shade to the skin (Olajubu \& Olupona 2003).

The deceased body is then wrapped in several native cloths, and positioned on a mat at the door of the room. At this point a fowl which is called Adie-Irana (the farefowl) is slain in order to make the road stress-free for the deceased as his journey into heaven. While the lying-in-state is going on, a yam is prepared and a share of it is positioned at the foot of the platform where the corpse is laid. This food is considered as food for the departed while the principal mourners, the widows and daughters of the deceased are isolated and exempted in the death-feast that follows (Ellis 1999).

In the Yoruba tradition, the actual burial of the corpse is a preceding event to the funeral process. During the interment, the offspring, relations, associates and 
neighbours of the deceased gather round the grave with gifts and other material things meant for the use of the deceased in heaven (Idowu 1967). As the gifts are offered to the deceased, the deceased is beseeched by those offering them to accept the gifts and not to sleep wherever he may be but watch over the offspring, the possessions he has left behind and also to be prepared to protect them anytime when they call on him.

Afterwards the $B i$ ba oku ya'hun rite (entering into a covenant with the deceased) is performed. This rite is performed in order to discontinue any physical association or relationship between the deceased and the living and for the living to bid farewell to the dead as well as impresses it upon the deceased that at the moment he is no longer in his former mortal state but have its place in another realm. And that he/she now has the obligation of watching over and defending those he left behind.

According to Idowu (1967) this rite is performed by the priest who descends into the grave and slaughters the sacrificial victim. He splits kola nuts and places certain items such as food, by the body. Worth to note that the Yoruba funeral rites, according to Drewal (1992) include seven days of ritual called etutu, which are performed to transfer the spirit of the dead to the land beyond where it remains alongside with other ancestral spirits. The first day of the ritual is known as ojo isinku (the day of interment), the third day is for feasting and is called itaoku, the seventh day, ije oku or ojo ije is meant for public celebration.

Among the Christians it is a usual practice to leave the corpse in the mortuary for days or weeks or even several months while the family make arrangements to give the deceased a befitting funeral. Christianity permits the use of casket for burial which commonly come in various shapes, sizes, pattern and occasionally very exceptional and colourful. The value of the casket may also suggest the social status of the deceased while alive or that of the family he belonged to while on earth. In the recent years it has become noticeable among Yoruba families to organize uniforms for the mourners and sympathisers as well as funeral celebrations called aso ebi, Oludayo (2020) in order to make the funeral ceremony very colourful and elaborate.

Usually, widows are expected to dress in black or white to mourn her deceased husband. In some cases, however, her entire head hairs are shaved during this period as a sign of morning of her late husband. It is also a shared practice among the Yoruba' that, if a young person dies, everyone attending the funeral is anticipated to appear in dark coloured clothes as a sign of mourning of the departed soul. After the interment the mourners celebrate the life of the deceased with song and dance. But the burial of the 
aged parents or rich individuals is usually followed with heavy feasting accompanied by singing and dancing to a mix of African beats. The Yoruba' are also fond of coming back a few years later for the dead remembrance celebration, some form of second burial or commemoration in honour of the dead. They perform rites and arrange celebrations where family members and friends come together to celebrate the departed.

For the Yoruba Muslims, the burial rites are somehow complex. But most of the funeral rites being performed by the Muslims are targeted towards respecting the body of the deceased as much as possible, bearing in mind that the departed soul will soon be presented to Allah. At the point of death, it is expected that family members and very close associates are present to offer the dying Muslim hope and kindness, as well as encouragement to say the shahada confirming that there is no God but Allah. However as soon as death has occurred, the people present are expected to say, Inna lillahi wa inna ilayhi raji'un meaning (Verily we belong to Allah, and truly to Him shall we return), while they close the eyes of the dead, lower its jaw, and cover the body of the dead with a clean sheet while they make $d u a$ (supplication) to Allah to forgive the sins of the departed (Smith 2004).

In Islam the body of the deceased is expected to be buried as soon as possible meaning that the funeral rites begin immediately after death. Embalming and cosmetology are not allowed unless required by state or federal law hence the urgency with which the body must be buried. Viewing of the body before the burial as well as cremation is also not allowed. In order to prepare the body of the deceased for burial, it must be washed Ghusl and shrouded Kafan while funeral prayers Salat al-Janazah should be performed before burial.

After the funeral and burial of the deceased, the immediate family members and friends will gather and receive and entertain visitors. It is accustomed for the deceased community to provide food for the family for the initial three days of the mourning period. Even though the mourning period among the Muslims generally lasts for 40 days, sometime depending on the degree of devoutness of the family, the mourning period may be shorter. Furthermore, even though it is tolerable in Islam to express grief over the death of a loved one through crying and weeping at death, at the funeral, and at the burial, yet, wailing and screaming, breaking of objects, shredding of clothing and articulating a lack of faith in Allah are frowned at. 


\section{Methodology}

The current study employed a qualitative research method. Primary data for the study was retrieved from 20 participants that were selected through snowball sampling method. Data collection was done through in-depth interview involving pre-set structured interview guide using a tape recorder. The study was conducted within a period of two (2) months between September and October 2021. Out of the participants in the study, twelve were male while the remaining eight were female. All the participants were Christians because Christians are accustomed to flamboyant ceremonies when burying their dead. Almost all the participants in the study eighteen (18) are married while all are from the Yoruba ethnic group mainly from the south western part of Nigeria. Only participants who bury the dead of a Yoruba person or present at the funeral were included in the study.

Interview was conducted mainly in English and Yoruba languages with a few communications in pidgin language (a mixture of English and local languages) which were translated by the researcher. Most of the interviews did not go beyond 20 minutes while majority of the interviews conducted were face-to-face but for participants that reside in locations very far from the reach of the researcher, such interviews were conducted over the phone. After completion of interview, transcripts were imported to the qualitative data analysis program ATLAS.ti version 8, the Knowledge Workbench. Collaborative coding of the field data and interviews was done through an inductive coding scheme. Formal data analysis began by unitizing data then comparing and sorting units into codes in ATLAS.ti. Codes were also compared to discern patterns and themes. To preserve the voice of the participants, full interview details were transcribed. Informed consent was appropriately obtained from all the participants after the researcher has carefully explained the objectives of the study to them. Privacy, anonymity, justice, confidentiality and respect for persons were ensured in the course of the study and beyond. Participants' identities were treated with anonymity as participants were represented with pseudo names occupation and age. 


\section{The effects of COVID-19 pandemic protocols and guidelines on the Yoruba funeral rites}

Following a series of interview conducted with participants in the study, the effects of COVID-19 pandemic preventive guidelines and protocols on the Yoruba funeral rites was categorized under the following themes.

\section{Grieving and mourning}

From the interviews conducted among participants in the study, it was noted that the COVID-19 pandemic guidelines and protocols affected the way participants were able to grieve and mourn the death of their loved ones. One of the participants who lost her mother at the age of 84 during the nationwide lock down occasioned by the COVID-19 pandemic had this to say.

...I couldn't even grieve or mourn my mummy the way I would have loved to. You know that among the Yoruba' when someone dies, a lot of people come around while some are crying others are pacifying the bereaved. There was nothing like that, we were all very afraid of the disease and we couldn't allow too many people to come in and mourn with us.... (Mrs Tade, Public servant, 43 years).

Similarly, another participant in the study who lost his brother inlaw at the age of 75 and visited the wife of the bereaved immediately after the demise of his inlaw was announced said this.

...It is very unlike the Yoruba way of grieving and mourning. Although people came around, they were too far from one another because they were observing social distancing. Even the wife of the dead was mourning alone only very few people with face mask were able to move close to her at various intervals, it really affected us... (Mrs Ogidan, retiree, 73 years).

\section{Making funeral arrangement}

The COVID-19 guidelines and protocols also to a large extent affected funeral arrangements among the Yoruba people. It was noted from the interview that the usual Yoruba funeral arrangement was altered due to the fact that the guidelines and protocols would be observed. This was what one of the participants in the study said:

...Honestly, there was no preparation at all because of the limited number of people required by government to be present at gatherings. We just buried our father and postponed the ceremony till after the lockdown. It was really painful 
that we couldn't even bury our daddy the way we should have done if not for the pandemic...(Mr Akinlolu, public servant, 38 years).

In the same vein, another participant in the study who had a similar experience also had this to say:

...Most of the preparation was done on the phone, we were all afraid of the pandemic so we limited the number of meetings that we had as well as the number of people that could be present. It was strictly restricted to close family members under stringent conditions...(Mr Shola, Businessman, 46 years).

Likewise this participant to share a similar experience, she said thus:

... When my daddy died it was in the midst of the lockdown and we didn't want his body to stay too long in the mortuary since we did not know how long the lockdown would last we had to bury him like that. Most of the preparation was done by close family members with very little contact many of which were done on the phone. And because the final ceremony was postponed indefinitely, there was nothing much to prepare for rather than to bury him immediately....(Mrs Adebayo, Businesswoman, 35 years).

Similarly another participant in the study said thus:

...You know in Yoruba land, when someone dies especially an elderly person, the elders in the family will come together, sit down and have meetings upon meetings to come up with modalities on how the dead person will be buried, but because of the prevailing circumstances in the country as of that time, this could not be done... (Mr Dada, artisan, 34 years)

However, a participant in the study shared his dismay on how the COVID-19 pandemic guidelines and protocols affected the family while preparing for the burial. This was what he said:

...The pandemic affected the preparation for the burial negatively in the sense that we had to pay double the expenses that we made after the lockdown when we eventually did the final burial ceremony. My dad died before the nationwide lockdown in Nigeria and we had already fixed April for the final burial ceremony without knowing that there was going to be lockdown. We made invitation cards already, we already picked aso-ebi (ceremonial dress for friends and families), we had paid for the musician and the venue for the ceremony and we couldn't recover the money. At the long run after the lockdown when we eventually wanted to do the final ceremony we had to start paying again for all these expenses that we have paid for. You can imagine the loss...(Mr Bamidele, businessman, 38 years).

\section{Funeral service and burial}

In addition to the aforementioned, we discover from the interviews held with the participants in the study that the COVID-19 pandemic guidelines and protocols affected the way and manner in which burial was done and the funeral service. One of the 
participants who lost his dad during the nationwide lockdown shared his experience and had this to say.

...It was just unfortunately that my dad died during the nationwide lockdown. Where I come from funeral rites usually last for three days before the dead can be buried. For example, on the first night, there is usually a vigil that is held by the family members where they sing and make merry all through the night to show that the deceased is an elderly person and has children. On the second day all the inlaws (husbands of the children) will also do the same and this continues till the third day before the dead can be buried. Unfortunately because of lockdown we were not able to observe these funeral rites for my dad which was very unfortunate. It was even more painful, that some of my siblings who live far away from where my dad was couldn't come to pay their last respect to their dad because of the nationwide lockdown, you can imagine the trauma.... $(\mathrm{Mr}$ Olusoji, student, 24 years).

In the same vein, a widow that was interviewed in the study also shared a similar experience and said thus.

...The lockdown really messed up a lot of things. Imagine burying my brother just like that without the usual traditional funeral rites that we are used to among my people. Only few family members and the pastors were at the grave side. We couldn't even hold a funeral service for him. Everything was done at the grave side. It gives me some kind of psychological trauma anytime I remember this. Honestly it pains me deep inside that we couldn't bury him the way he deserved.... (Mrs Akinshola, retiree, 66 years).

Another participant in the study also said thus:

...The burial was done among just close family members. We tried our best to keep to the required number of people recommended by the government for gatherings which was 20 people then. Only the children, the deceased wife and the pastors were present at the burial. Ifelt very bad because of his social status and the position he occupied among his people he deserved more than that ...(Mrs Bola, banker, 40 years).

This was also similar to what this other participants said, hear him:

...We tried our best to ensure that too many people were not present at the burial of our father because of the fear we had for the disease and of course in order to comply with the government guidelines and protocols. As a matter of fact we had to employ security men to stand at the gate of our house so that people do not gain free access to the venue of the burial. Everyone that was present was with his face mask and sanitizers. You know the way it was that time? Nobody knows who is carrying the virus, so we were very careful...(Mr Babatope, Engineer, 45 years).

Likewise this participant had this to say: 
...I am not happy the way things turned out. The pandemic really affected my mom's funeral rites in a big way. You can imagine we didn't even hold a funeral service for him in the church because we were afraid that we were going to have too much crowd. Everything was done at the graveside as if she was nobody... (Kunle, Public servant, 36 years).

\section{Burial ceremony}

Some of the participants in the study revealed that the COVID-19 pandemic preventive guidelines and protocols affected the burial ceremonies, while some of them only buried their dead and that was all, some others had to postpone the burial to give their loved ones a more befitting burial. Listen to this participant.

...We couldn't do any ceremony, it was in the midst of the pandemic that our father died and there were a number of restrictions from the government at that time which worked against us so we had to bury him on a low key...(Miss Shade, trader, 22 years).

This next participant also shared her experience, this was what he said:

...We couldn't afford not to give our father a befitting burial we had to postpone the burial to a later date. However when it seemed as if the pandemic was not going to end we managed to do the final burial ceremony but it wasn't as flamboyant as expected. The number of guests was still limited and people came with their face masks and sanitizers. We didn't like it that was but we couldn't help the situation....(Bayo, security expert, 47 years).

This was also similar to what this participant said:

...When our mom died, we couldn't do the burial ceremony immediately because of the limited number of people required to gather in places as of that time so we had to postpone the final burial ceremony till the one year remembrance when we believe the pandemic would have gone down... (Kola, teacher, 33 years).

\section{Discussion}

The first effect of COVID-19 pandemic guidelines and protocols on the Yoruba funeral rites that was observed in the study is on grieving and mourning. According to the participants in the study, the usual cultural way of grieving and morning peculiar to the Yoruba people was conspicuously absent because of social distancing and the use of face mask and other preventive guideline and protocols laid down by the government. This corresponds to the findings of the study conducted by Omonisi (2020) who asserted that who asserted that only few of people typically less than 20 people were 
permitted to mourn and grief the deceased at the mortuaries while those allowed in are also asked to use face masks and also observe the social distancing and other rules associated in containing the COVID-19 pandemic.

The effect of the COVID-19 pandemic guidelines and protocols was also observed in the area of making preparations for the burial of the deceased during the pandemic. It was observed in the study that some of the participants couldn't gather to make preparations for the burial of their loved ones because of the limited number of people that were required to gather during the COVID-19 lockdown in the country. Besides, because of the lockdown and the prohibition of international and interstate travel, it was difficult for people to travel and move around making it even more difficult for people to appear physically to prepare for the funeral arrangements. This confirms the view of Mbah (2020) who asserted that ban of interstate and international travel as well as mass gathering of not more than 20 or 50 persons depending on the location was prohibited in Nigeria during the lockdown in order to contain the ongoing COVID-19 pandemic.

Furthermore, findings from the study also suggest that the COVID-19 guidelines and protocols affected the funeral service and the burying of the dead. While some of the participants in the study were unable observe the usual funeral rites they are accustomed to, It was observed that among the participants, others had to adhere strictly to washing or sanitizing of their hands, social distancing and particularly limited number of people at burial to just immediate family and clergy. More importantly is the fact that some of the participants were unable to hold a funeral service for their loved ones because of the fear that there could be a large turnout of people basically family and friends. This however contradicts the view of Aborisade (2015) who opined that funeral rites among the Yoruba' is not just limited to burying the corpse but involves a chain of rituals that is performed prior and after burial of the deceased.

Lastly, we observed from the study that the COVID-19 preventive guidelines and protocols affected the Yoruba funeral rites in the area of final burial ceremony. Some of the participants expressed dismay on their inability to give their loved ones a befitting burial. This was due to the fact that social distancing had to be observed and most importantly, limited number of people was required for burial ceremonies. This was different from the usual burial ceremony that the Yoruba' who are very expressive and exhibit rich, exuberant and ceremonial nature of their culture with colourful celebrations.are used to. Yoruba funeral ceremonies are usually very colorful and 
elaborate and families often times do organize uniforms for the mourners and sympathisers called aso ebi to grace the occasion (Oludayo 2020).

\section{Conclusion}

This study examined the effects of COVID-19 pandemic preventive guidelines and protocols on the Yoruba funeral rites. In order to achieve this 20 participants selected through snowball sampling method participated in the study. Information was retrieved through in depth interview from participants, while data analysis was done through the qualitative data analysis program ATLAS.ti version 8. Findings from the study revealed that the COVID-19 pandemic preventive guidelines and protocols affects the Yoruba funeral rites in the areas of grieving and mourning, preparation for burial, funeral service and burial as well as burial ceremony.

Conflicts of Interest: Authors declare no conflict of interest

\section{References}

Aborisade O. 2015. Suicide in Yoruba Ontology. International Journal of History and Philosophical Research. 3(1): 29-34.

Awolalu O., Dopamu A.P. 2005. West African Tradition Religion. lbadan: Macmillan Nigeria Publishers Ltd.150.

Centers for Disease Control and Prevention. 2020. Symptoms of Coronavirus.

Retrievedfrom:https://www.cdc.gov/coronavirus/2019-ncov/symptomstesting/symptoms.html?CDC_AA_refVal=https\%3A\%2F\%2Fwww.cdc.gov\%2Fcorona virus\%2F2019-ncov\%2Fabout\%2Fsymptoms.html. Accessed September 3, 2020.

Dopamu A.P. 2006. Change and Continuity: The Yoruba Belief in Life after Death. A paper was prepared for "Continuity and Change: Perspectives on Science and Religion", June 3-7, 2006, in Philadelphia, PA, USA, a program of the Metanexus Institute. Retrieved from: http://www.obafemio.com/uploads/5/1/4/2/5142021/dopamulifeafter_death.pdf. Accessed 25 September 2020.

Drewal M.T.1992. Yoruba Ritual: Performer, Plays and Agency. African Systems of Thought. Bloomington: Indiana UP. ISBN: 9780253112736 
Ellis A.B. 1999. The Yoruba - Speaking People of the Slave Coast of West Africa. Their Religion Manners, Customs, Laws and Language. Kessinger Legacy reprints. ISBN: 1162937513

Garcia S.E., MzezewaT., VigdorN., Zaveri M ., ZraickK ., Sisario B, Anderson M. 2020. A list of What's Been Canceled Because of the Coronavirus. Retrieved from: https://www.nytimes.com/article/cancelled-events-coronavirus.html. Accessed September 32020

Hunwick J.O. 1992. Religion and National Integration in Africa: Islam, Christianity, and Politics in the Sudan and Nigeria. North-western University Press. 103

Idowu E.B. 1967. Olodumare: God in Yoruba Belief. London: Longman.169.

Klaudia K. 2021. Nigerian Funerals: Customs, Ceremony \& What to Expect. Retrieved from: https://www.joincake.com/blog/nigerian-funeral/.

Mbah F. 2020. Nigerian announces lockdown of major cities to curb coronavirus. Retrieved from: https://www.aljazeera.com/economy/2020/03/30/nigeriaannounces-lockdown-of-major-cities-to-curb-coronavirus/.

Olajubu O., Olupona J.K. 2003. Women in the Yoruba Religious Sphere State. University of New York Press, Albany.

Oludayo T. 2020. Nigeria's tradition of matching outfits at events has a downside. Retrieved from: https://theconversation.com/nigerias-tradition-of-matching-outfits-atevents-has-a-downside-131235. Accessed 28 September 2020.

Omonisi A.E. 2020. How COVID-19 pandemic is changing the Africa's elaborate burial rites, mourning and grieving. Pan African Medical Journal. 35(2) 81. DOI: 10.11604/pamj.supp.2020.35.2.23756.

Robertson R. 1969. Sociology of Religion.Harmondsworth, Middlesex: PensuinX Book Ltd, 57.

Smith D.J. 2004. Burials and belonging in Nigeria: Rural-Urban Relations andSocialInequality in a Contemporary African Ritual. American Anthropologist. 106(3): 569-579

World Factbook. 2020. Yorùbá 21.1\%" out of a population of 206 million 2020 estimate. Nigeria country profile at CIA's. Retrieved from: https://www.cia.gov/library/publications/the-world-factbook/geos/ni.html. Accessed $23^{\text {rd }}$ September 2020.

World Health Organization. 2020. Q \& A on coronaviruses (COVID-19). Retrieved from:

https://web.archive.org/web/20200514224315/https://www.who.int/emergencies/disease s/novel-coronavirus-2019/question-and-answers-hub/q-a-detail/q-acoronaviruses. Accessed September 3, 2020 
To cite this article:

Joseph A.O., Fagbamila O.D., Joseph A.A. 2021. COVID-19 pandemic preventive guidelines and protocols: How does this affect the Yoruba funeral rites in Nigeria.

International Journal of Modern Anthropology. 2 (16): 570 - 585

DOI: http://dx.doi.org/10.4314/ijma.v2i16.3

\section{(2) $(\oplus \Theta \Theta$}

This article, as all articles published in this journal, is under The Creative Commons Attribution: Attribution-NonCommercial-NoDerivatives 4.0 International (CC BY-NC-ND 4.0). https://creativecommons.org/licenses/by-nc-nd/4.0/ 